CLINICAL STUDY

\title{
Effects of oral and transdermal estrogen on IGF 1, IGFBP3, IGFBP1, serum lipids, and glucose in patients with hypopituitarism during GH treatment: a randomized study
}

\author{
Ana Lúcia Isotton ${ }^{1,2}$, Maria Celeste Osorio Wender ${ }^{1,2}$, Alessandra Casagrande ${ }^{1,2}$, Guilherme Rollin ${ }^{1,2}$ \\ and Mauro Antônio Czepielewski ${ }^{1,2}$ \\ ${ }^{1}$ Endocrinology Department, Hospital de Clínicas de Porto Alegre, Porto Alegre, RS, Brazil and ${ }^{2}$ Medical Sciences Graduate Program: Endocrinology, School \\ of Medicine, Universidade Federal do Rio Grande do Sul (UFRGS), Porto Alegre, RS, Brazil
}

(Correspondence should be addressed to M A Czepielewski who is now at Serviço de Endocrinologia do Hospital de Clínicas de Porto Alegre, Rua Ramiro Barcelos 2350, Prédio 12, $4^{\circ}$ andar, CEP 90035-003 Porto Alegre, RS, Brazil; Email: maurocze@terra.com.br)

\begin{abstract}
Objective: To evaluate the effects of oral estradiol and transdermal $17 \beta$-estradiol on serum concentrations of IGF1 and its binding proteins in women with hypopituitarism.

Design: Prospective, comparative study.

Methods: Eleven patients with hypopituitarism were randomly allocated to receive $2 \mathrm{mg}$ oral estradiol $(n=6)$ or $50 \mu \mathrm{g}$ /day of transdermal $17 \beta$-estradiol $(n=5)$ for 3 months.

Results: The oral estrogen group showed a significant reduction in IGF1 levels (mean: 42.7\% \pm 41.4 , $P=0.046)$; no difference was observed in the transdermal estrogen group. There was a significant increase in IGFBP1 levels (mean: $170.2 \% \pm 230.9, P=0.028$ ) in the oral group, but not in the transdermal group. There was no significant difference within either group in terms of median IGFBP 3 levels. In relation to lipid profiles, there was a significant increase in mean high-density lipoprotein cholesterol levels in the oral group after 3 months of treatment, $(27.8 \pm 9.3, P=0.003)$. We found no differences in the anthropometric measurements, blood pressure, heart rate, glucose, insulin, C-peptide, or the homeostasis model assessment index after treatment.

Conclusions: Our preliminary data indicate that different estrogen administration routes can influence IGF1 and IGFBP1 levels. These findings in patients with hypopituitarism have an impact on their response to treatment with $\mathrm{GH}$, since patients receiving oral estrogen require increased GH dosage. These results suggest that oral estrogens may reduce the beneficial effects of GH replacement on fat and protein metabolism, body composition, and quality of life.
\end{abstract}

European Journal of Endocrinology 166 207-213

\section{Introduction}

There is considerable evidence that the use of estrogens by women has an influence on the GH/IGF1 axis (1). Small intervention studies $(2,3,4,5,6,7,8,9,10)$ and large cross-sectional studies $(11,12,13,14,15)$ have demonstrated that oral estrogens reduce serum concentrations of total IGF1. These findings have been observed both in menopausal women and in those with hypopituitarism.

It is presumed that oral estrogen inhibits the secretion/production of IGF1 by means of a first-pass hepatic effect, causing an increase in $\mathrm{GH}$ secretion by inhibiting the negative feedback of IGF1 $(1,6)$. In a study on women with GH deficiency, IGF1 levels were significantly higher during $100 \mu \mathrm{g}$ transdermal estradiol treatment compared with $2 \mathrm{mg}$ oral treatment (16). In GH-deficient patients, these changes compromise the
GH action and, consequently, suppress lipid oxidation and cause changes in body composition (17).

Studies investigating the transdermal administration of estrogen in normal menopausal women have demonstrated that this route of administration has effects on serum IGF1 concentrations. An increase or absence of effect has been demonstrated probably because estrogen does not undergo hepatic metabolism and accesses systemic circulation directly $(2,18,19,20,21)$.

Around $75 \%$ of IGF1 circulates in plasma by formation of a ternary complex with IGFBP 3 and the acid-labile subunit. Studies of oral estrogens have provided inconsistent results in relation to IGFBP 3 concentrations, with reports of reduced serum levels $(5,7,13$, $22,23)$ or an absence of effects $(2,4,6,12,14,15)$.

IGFBP 1, an insulin-modulated binding protein of IGF, regulates the rate of free IGF1. Serum IGFBP1 levels are inversely related to the development of diabetes mellitus 
Table 1 Sample characteristics at baseline.

\begin{tabular}{ll}
\hline Characteristics & Values \\
\hline$n$ & 11 \\
Age (years) & a \\
Skin color & $36.1 \pm 10.2$ \\
White & \\
Black & $10(90.9)$ \\
Weight $(\mathrm{kg})^{\mathrm{a}}$ & $1(9.1)$ \\
Height $(\mathrm{m})^{\mathrm{a}}$ & $59.7 \pm 10.4$ \\
$\mathrm{BMI}^{\mathrm{a}}\left(\mathrm{kg} / \mathrm{m}^{2}\right)^{\mathrm{a}}$ & $1.55 \pm 0.04$ \\
WHR $^{\mathrm{a}}$ & $24.7 \pm 3.9$ \\
\end{tabular}

BMI, body mass index; WHR, waist-hip ratio.

a Mean \pm s.D.

${ }^{\mathrm{b}} n(\%)$.

type 2, particularly in the presence of reduced IGF1 concentrations (24). Helle et al. (6) demonstrated a $46 \%$ increase in serum IGFBP1 levels after use of oral estrogens, and their findings were later confirmed by other authors $(4,5)$.

The primary objective of this study was to investigate the interrelationships between estrogen administration routes and concentrations of IGF1 and its binding proteins in patients with hypopituitarism during GH-replacement treatment. In these GH-deficient patients, GH secretion cannot be modulated by estrogen. Therefore, any changes in GH secretion will be caused by other metabolic effects, regardless of $\mathrm{GH}$ secretion.

\section{Patients and methods}

The study sample comprised 11 female patients with organic and secondary hypopituitarism, aged 18-50 years (Table 1), and selected from a group of 36 women with hypopituitarism treated at the neuroendocrinology clinic at the Hospital de Clínicas de Porto Alegre (HCPA), Southern Brazil. The study was approved by the research ethics committee at HCPA, and all patients who agreed to participate in the study signed a free and informed consent form. Hypopituitarism was diagnosed by assaying the basal hormones $\mathrm{T}_{4}, \mathrm{TSH}$, estradiol, LH, FSH, cortisol, ACTH, and IGF1. GH deficiency was diagnosed by insulin-induced hypoglycemia $(n=5)$ or glucagon stimulation test $(n=6)$, with patients considered normal if their $\mathrm{GH}$ peak was $>3 \mathrm{ng} / \mathrm{ml}$ (Table 2). All patients were receiving regular treatment to correct other hormone deficiencies. With relation to $\mathrm{GH}$, at the study outset, patients had been on $0.5 \mathrm{IU} /$ day of Norditropin (Novo Nordisk, Sao Paulo, Brazil) for at least 2 months and presented normal IGF1 levels for their ages. The majority of the patients had not been given gonadal steroids (6/11), and those who had taken them (5/11) had had them withdrawn at least 3 months before the study began.

Patients were excluded if they were diabetic, obese, had liver or kidney disease, or if they were $<18$ or $>50$ years old. Patients with previous endocrinopathies did not have any active diseases during the study.

The patients selected were randomized to receive equivalent doses of estradiol by different administration routes: $2 \mathrm{mg}$ estradiol orally (Estrofem, Novo Nordisk) or $50 \mu \mathrm{g} /$ day of transdermal estradiol for 3 months (System, Janssen-Cilag, Sao Paulo, Brazil); subsequently, $1 \mathrm{mg}$ oral norethisterone (Micronor, Janssen-Cilag) was added for a further 3 months to provide endometrial protection.

\section{Assays and methods employed}

IGF1 concentrations were determined by IRMA, DSL5600 Active (Diagnostic System Laboratories, Inc., Webster, TX, USA), with intra- and inter-assay coefficients of variation (CV) of 3.9 and $4.2 \%$, respectively, by the HCPA RIA Laboratory, Porto Alegre, Brazil.

IGFBP3 levels were determined by IRMA, DSL-6600 Active (Diagnostic System Laboratories, Inc.), with intra- and inter-assay CV of 3.9 and $0.6 \%$, respectively, by Instituto Fleury, São Paulo, Brazil.

IGFBP1 concentrations were determined by IRMA, DSL-7800 Active (Diagnostic System Laboratories, Inc.), with intra- and inter-assay $\mathrm{CV}$ of 2.7 and $3.6 \%$, respectively, by the Nichols Institute, USA.

The remaining hormone assays were performed at the HCPA RIA Laboratory; estradiol and C-peptide were measured using the chemiluminescence immunoassay (CLIA) method, and insulin was assessed by the RIA method.

Ultra-sensitive C-reactive protein was measured by nephelometry with CardioPhase hsCRP reagents (Dade Behring, Inc., Deerfield, IL, USA); intra- and inter-assay CV were 3.1 and $2.5 \%$ respectively.

Table 2 Clinical characteristics of women $(n=11)$ with hypopituitarism.

\begin{tabular}{|c|c|}
\hline Clinical characteristics & Values \\
\hline \multicolumn{2}{|l|}{ No. of hormone deficiencies ${ }^{a}$} \\
\hline Gonadotropic & $11(100 \%)$ \\
\hline Thyrotropic & $8(72.7 \%)$ \\
\hline Somatotropic & $11(100 \%)$ \\
\hline Corticotropic & $9(81.8 \%)$ \\
\hline \multicolumn{2}{|l|}{ Causes of hypopituitarism ${ }^{a}$} \\
\hline Cushing's disease & $6(54.5)$ \\
\hline Craniopharyngioma & $2(18.2)$ \\
\hline Dysgerminoma & $1(9.1)$ \\
\hline Empty sella & $1(9.1)$ \\
\hline Sheehan's syndrome & $1(9.1)$ \\
\hline Surgery ${ }^{a}$ & $9(81.8)$ \\
\hline Radiotherapy ${ }^{a}$ & $2(18.2)$ \\
\hline \multicolumn{2}{|l|}{ Test $^{\mathrm{a}}$} \\
\hline Glucagon & $6(54.5)$ \\
\hline Insulin hypoglycemia & $5(45.5)$ \\
\hline Time using $\mathrm{GH}$ (months) ${ }^{\mathrm{b}}$ & 7 (2-19) \\
\hline
\end{tabular}


Biochemical tests were performed according to the HCPA General Laboratory's routine methods. The homeostasis model assessment-insulin resistance (HOMA-IR) index was used to detect IR. It was calculated using the formula HOMA-IR $=(($ fasting glycemia in $\mathrm{mg} / \mathrm{dl} \times 0.05551) \times$ fasting insulin in $\mu \mathrm{U} / \mathrm{ml}) / 22.5$.

The following clinical variables were assessed: weight, body mass index $\left(\mathrm{BMI}=\right.$ weight $/$ height $\left.^{2}\right)$, arterial blood pressure, and waist-hip ratio (the greatest diameter of each circumference was taken into consideration). To investigate possible estrogen-related effects, endometrial thickness was also assessed by transvaginal ultrasound, using a General Electric (GE) LOGIC 200 PRO, with an endocavity transducer at a frequency of $7.5 \mathrm{MHz}$.

\section{Statistical analysis}

Quantitative variables were described as means and s.D. when symmetrical, or as medians and amplitude of variation (maximum - minimum) when asymmetrical. Categorical variables were described in terms of absolute and relative frequencies.

Student's $t$-test was used to compare the groups (oral vs transdermal) in terms of quantitative variables with normal distribution. In cases of asymmetry, the Mann-Whitney $U$ test was applied.

To compare baseline assessments vs results after 3 months on estrogen administered by the different routes, the $t$-test for paired samples or the Wilcoxon test was applied, depending on the distribution of each variable.

Pearson's correlation coefficient was used to analyze associations between variations observed in the third month vs baseline data.

The level of significance adopted was 5\%, and $P \leq 0.05$ was considered statistically significant. Data were analyzed using the Statistical Package for the Social Sciences (SPSS Inc., New York, NY, USA) version 12.0.

\section{Results}

The sample comprised 11 patients with a mean age of $36.1( \pm 10.2)$ years and were predominantly of white skin color $(90.9 \%$ of cases) (Table 1$)$. With relation to the clinical characteristics of the sample, all women showed somatotropic and gonadotropic deficiencies, and $54.5 \%$ of them presented Cushing's disease as a previous endocrinopathy, the treatment for which resulted in their hypopituitarism (Table 2).

At the study outset, patients in the oral and transdermal groups were similar in terms of IGF1, IGFBP1, and IGFBP 3 levels and other study variables (Table 3 ).

Over the 3 months of treatment, mean serum estradiol levels increased from $10.1(5-54.7)$ to $133.9 \mathrm{pg} / \mathrm{ml}$ (7.4-197.9), $P=0.046$ (median - minimum - maximum) in the oral group. In the transdermal group, mean estradiol levels increased from $12.7(7.4-33.4)$ to $36.1 \mathrm{pg} / \mathrm{ml}$ (17.4-84.4), $P=0.043$ (Table 4).

Table 3 Comparison between the two groups at baseline.

\begin{tabular}{|c|c|c|c|}
\hline Variables & Oral route $(n=6)$ & Transdermal route $(n=5)$ & $\boldsymbol{P}$ \\
\hline Weight $(\mathrm{kg})^{\mathrm{a}}$ & $60.8 \pm 14.2$ & $58.4 \pm 3.6$ & $0.724^{b}$ \\
\hline Height $(\mathrm{m})^{\mathrm{a}}$ & $1.56 \pm 0.03$ & $1.55 \pm 0.05$ & $0.908^{\mathrm{b}}$ \\
\hline BMI $\left(\mathrm{kg} / \mathrm{m}^{2}\right)^{\mathrm{a}}$ & $24.9 \pm 5.2$ & $24.2 \pm 2.2$ & $0.783^{\mathrm{b}}$ \\
\hline $\mathrm{WHR}^{\mathrm{a}}$ & $0.97 \pm 0.05$ & $0.94 \pm 0.04$ & $0.285^{b}$ \\
\hline Systolic BP $(\mathrm{mmHg})^{\mathrm{a}}$ & $115.5 \pm 13.8$ & $123.7 \pm 20.9$ & $0.459^{b}$ \\
\hline Diastolic BP $(\mathrm{mmHg})^{\mathrm{a}}$ & $76.9 \pm 12.8$ & $83.3 \pm 13.9$ & $0.452^{\mathrm{b}}$ \\
\hline $\mathrm{HR}(\mathrm{bpm})^{\mathrm{a}}$ & $81.3 \pm 11.8$ & $75.2 \pm 11.4$ & $0.405^{b}$ \\
\hline Endometrial thickness $(\mathrm{cm})^{\mathrm{c}}$ & $0.2(0.1-0.8)$ & $0.3(0.1-0.4)$ & $0.931^{d}$ \\
\hline Estradiol $(\mathrm{pg} / \mathrm{ml})^{\mathrm{c}}$ & $10.1(5-54.7)$ & $12.7(7.4-33.4)$ & $0.662^{d}$ \\
\hline IGF1 (ng/ml) ${ }^{\mathrm{C}}$ & $195.6(40.7-461.5)$ & $166.5(148.8-340.4)$ & $0.662^{d}$ \\
\hline IGFBP3 $(\mathrm{ng} / \mathrm{ml})^{\mathrm{C}}$ & $3480(1370-5376)$ & $2877(2140-4730)$ & $0.662^{d}$ \\
\hline IGFBP1 $(\mathrm{ng} / \mathrm{ml})^{\mathrm{c}}$ & $14.9(5.0-56.2)$ & $29.9(5.0-49.7)$ & $0.537^{\mathrm{b}}$ \\
\hline Glucose $(\mathrm{mg} / \mathrm{ml})^{\mathrm{a}}$ & $96.5 \pm 9.9$ & $84.8 \pm 10.7$ & $0.092^{d}$ \\
\hline Insulin $(\mu \mathrm{IU} / \mathrm{ml})^{\mathrm{c}}$ & $11.9(2.1-23.1)$ & $3.10(2.7-24.3)$ & $0.429^{b}$ \\
\hline C-peptide $(\mathrm{ng} / \mathrm{ml})^{\mathrm{a}}$ & $1.52 \pm 0.80$ & $1.58 \pm 0.85$ & $0.904^{d}$ \\
\hline HOMA $^{\mathrm{C}}$ & $5.22(4.72-6.10)$ & $4.38(4.22-5.55)$ & $0.126^{b}$ \\
\hline Total cholesterol $(\mathrm{mg} / \mathrm{dl})^{\mathrm{a}}$ & $222.0 \pm 27.5$ & $235.8 \pm 70.6$ & $0.698^{\mathrm{b}}$ \\
\hline $\mathrm{HDL}(\mathrm{mg} / \mathrm{dl})^{\mathrm{a}}$ & $54.0 \pm 19.3$ & $61.4 \pm 13.0$ & $0.486^{\mathrm{b}}$ \\
\hline $\operatorname{LDL}(\mathrm{mg} / \mathrm{dll})^{\mathrm{a}}$ & $188.4 \pm 53.1$ & $157.5 \pm 80.5$ & $0.464^{b}$ \\
\hline Triglycerides $(\mathrm{mg} / \mathrm{dl})^{\mathrm{a}}$ & $231.2 \pm 116.1$ & $192.0 \pm 178.4$ & $0.671^{b}$ \\
\hline Ultra-sensitive C-reactive protein $\left(\mathrm{mg} / \mathrm{l}^{\mathrm{c}}\right.$ & $6.83(0.54-8.62)$ & $3.16(1.31-7.31)$ & $0.247^{d}$ \\
\hline Time on GH (months) ${ }^{\mathrm{c}}$ & $7.5(3-19)$ & $7.0(2-12)$ & $0.537^{d}$ \\
\hline Dose of GH (IU/day) ${ }^{\mathrm{C}}$ & $0.5(0.25-0.50)$ & $0.5(0.25-1.00)$ & $0.792^{d}$ \\
\hline
\end{tabular}

BMI, body mass index; WHR, waist-hip ratio; BP, blood pressure; HR, heart rate; HOMA, homeostasis model assessment.

${ }^{\mathrm{a}}$ Mean \pm S.D.

bStudent's $t$-test.

'Median (minimum-maximum).

dMann-Whitney $U$ test. 
Table 4 Comparison between study phases according to route of administration.

\begin{tabular}{|c|c|c|c|c|c|c|}
\hline \multirow[b]{2}{*}{ Variables } & \multicolumn{2}{|c|}{ Oral route $(n=6)$} & \multirow[b]{2}{*}{$P$} & \multicolumn{2}{|c|}{ Transdermal route $(n=5)$} & \multirow[b]{2}{*}{$P$} \\
\hline & Baseline & After 3 months & & Baseline & After 3 months & \\
\hline Weight $(\mathrm{kg})^{\mathrm{a}}$ & $60.8 \pm 14.2$ & $61.7 \pm 15.4$ & $0.280^{\mathrm{b}}$ & $58.4 \pm 3.6$ & $59.1 \pm 5.0$ & $0.581^{b}$ \\
\hline $\operatorname{BMI}\left(\mathrm{kg} / \mathrm{m}^{2}\right)^{a}$ & $25.0 \pm 5.2$ & $25.4 \pm 5.7$ & $0.272^{\mathrm{b}}$ & $24.3 \pm 2.3$ & $24.6 \pm 2.7$ & $0.593^{\mathrm{b}}$ \\
\hline$W H R^{a}$ & $0.97 \pm 0.05$ & $0.96 \pm 0.05$ & $0.576^{\mathrm{b}}$ & $0.94 \pm 0.04$ & $0.94 \pm 0.04$ & $0.374^{b}$ \\
\hline Systolic BP $(\mathrm{mmHg})^{\mathrm{a}}$ & $115.6 \pm 13.8$ & $118.2 \pm 20.5$ & $0.567^{\mathrm{b}}$ & $123.7 \pm 20.9$ & $121.3 \pm 15.7$ & $0.711^{\mathrm{b}}$ \\
\hline Diastolic BP $(\mathrm{mmHg})^{\mathrm{a}}$ & $77.0 \pm 12.8$ & $78.9 \pm 14.1$ & $0.619^{b}$ & $83.3 \pm 13.9$ & $86.6 \pm 11.8$ & $0.333^{b}$ \\
\hline $\mathrm{HR}(\mathrm{bpm})^{\mathrm{a}}$ & $81.3 \pm 11.8$ & $74.0 \pm 9.0$ & $0.202^{\mathrm{b}}$ & $75.2 \pm 11.4$ & $75.6 \pm 8.0$ & $0.914^{\mathrm{b}}$ \\
\hline Endometrial thickness $(\mathrm{cm})^{\mathrm{C}}$ & $0.2(0.1-0.8)$ & $0.9(0.3-1.5)$ & $0.027^{d}$ & $0.3(0.1-0.4)$ & $0.6(0.2-0.8)$ & $0.042^{d}$ \\
\hline Estradiol $(\mathrm{pg} / \mathrm{ml})^{\mathrm{c}}$ & $10.1(5-54.7)$ & $133.9(7.4-197.9)$ & $0.046^{d}$ & $12.7(7.4-33.4)$ & $36.1(17.4-84.4)$ & $0.043^{d}$ \\
\hline IGF1 (ng/ml) ${ }^{\mathrm{c}}$ & $195.6(40.7-461.5)$ & $91.3(34.1-203.9)$ & $0.046^{d}$ & $166.5(148.8-340.4)$ & $122.3(101.9-339.2)$ & $0.500^{d}$ \\
\hline IGFBP3 $(\mathrm{ng} / \mathrm{ml})^{\mathrm{C}}$ & $3480(1370-5376)$ & $2790(1530-6330)$ & $0.463^{\mathrm{d}}$ & $2877(2140-4730)$ & $3600(2830-3790)$ & $0.500^{d}$ \\
\hline 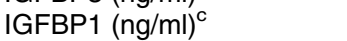 & $14.9(5.0-56.2)$ & $40.6(7.9-62.2)$ & $0.028^{d}$ & $29.9(5.0-49.7)$ & $12.2(5-41.1)$ & $0.144^{d}$ \\
\hline Glucose $(\mathrm{mg} / \mathrm{ml})^{\mathrm{a}}$ & $96.5 \pm 9.9$ & $89.0 \pm 7.5$ & $0.124^{\mathrm{b}}$ & $84.8 \pm 10.7$ & $84.0 \pm 6.4$ & $0.830^{\mathrm{b}}$ \\
\hline Insulin $(\mu \mathrm{IU} / \mathrm{ml})^{\mathrm{c}}$ & $11.9(2.1-23.1)$ & $10.2(1.8-32.5)$ & $0.893^{\mathrm{d}}$ & $3.10(2.7-24.3)$ & $5.79(2.82-10.9)$ & $0.686^{\mathrm{d}}$ \\
\hline C-peptide $(\mathrm{ng} / \mathrm{ml})^{\mathrm{a}}$ & $1.5 \pm 0.8$ & $2.0 \pm 1.4$ & $0.385^{\mathrm{b}}$ & $1.6 \pm 0.9$ & $1.2 \pm 0.5$ & $0.401^{b}$ \\
\hline $\mathrm{HOMA}^{\mathrm{C}}$ & $5.22(4.72-6.10)$ & $5.04(4.22-5.38)$ & $0.116^{\mathrm{d}}$ & $4.38(4.22-5.55)$ & $4.49(4.44-5.27)$ & $0.893^{d}$ \\
\hline Total cholesterol $(\mathrm{mg} / \mathrm{dl})^{\mathrm{a}}$ & $222 \pm 27.5$ & $239.3 \pm 36.4$ & $0.280^{\mathrm{b}}$ & $235.8 \pm 70.6$ & $224.0 \pm 71.1$ & $0.083^{b}$ \\
\hline $\mathrm{HDL}(\mathrm{mg} / \mathrm{dl})^{\mathrm{a}}$ & $54.0 \pm 19.3$ & $68.7 \pm 24.0$ & $0.003^{b}$ & $61.4 \pm 13.0$ & $61.4 \pm 19.7$ & $1.000^{\mathrm{b}}$ \\
\hline $\operatorname{LDL}(\mathrm{mg} / \mathrm{dl})^{\mathrm{a}}$ & $188.4 \pm 53.1$ & $177.4 \pm 56.0$ & $0.531^{\mathrm{b}}$ & $157.5 \pm 80.5$ & $152.5 \pm 68.2$ & $0.428^{b}$ \\
\hline Triglycerides $(\mathrm{mg} / \mathrm{dl})^{\mathrm{a}}$ & $231.2 \pm 116.1$ & $243.2 \pm 124.2$ & $0.679^{b}$ & $192.0 \pm 178.5$ & $159.4 \pm 119.6$ & $0.300^{\mathrm{b}}$ \\
\hline $\begin{array}{l}\text { Ultra-sensitive C-reactive } \\
\text { protein }\left(\mathrm{mg} / \mathrm{l}^{\mathrm{c}}\right.\end{array}$ & $6.8(0.5-8.6)$ & $5.0(1.5-10.3)$ & $0.917^{d}$ & $3.2(1.3-7.3)$ & $1.1(0.6-5.5)$ & $0.043^{d}$ \\
\hline
\end{tabular}

BMI, body mass index; WHR, waist-hip ratio; BP, blood pressure; HR, heart rate; HOMA, homeostasis model assessment. Values in bold indicate $P \leq 0.05$.

a Mean \pm S.D.

bStudent's $t$-test for paired samples.

${ }^{\mathrm{C}}$ Median (minimum - maximum).

dWilcoxon test.

Endometrial thickness, analyzed by transvaginal pelvic ultrasound, increased from 2 (1-8) to $9 \mathrm{~mm}$ (3-15), $P=0.027$ in the oral group. In the transdermal group, mean endometrial thickness increased from 3 (1-4) to $6 \mathrm{~mm}$ (2-8), $P=0.042$.

During treatment with oral estrogens, median IGF1 levels dropped significantly (mean $42.7 \% \pm 41.4$ ) in relation to baseline values, from 195.6 (40.7-461.5) to $91.3 \mathrm{ng} / \mathrm{ml}(34.1-203.9), P=0.046$. In the transdermal group, median IGF1 level at the start of treatment was $166.5 \mathrm{ng} / \mathrm{ml}$ (148.8-340.4), and after 3 months

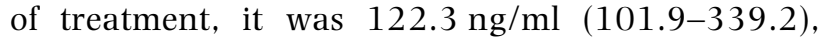
$P=0.500$. There was also no significant difference within each group with relation to median IGFBP3 levels.

In contrast, we observed significant increases in IGFBP1 levels in the oral group, a mean increase of $170.2 \%( \pm 230.9)$, varying from $14.9(5.0-56.2)$ at baseline to $40.6 \mathrm{ng} / \mathrm{ml}(7.9-62.2)$ at the end of the treatment, $P=0.028$. In the transdermal group, there was a non-significant reduction in IGFBP1 levels, with baseline results at $29.9 \mathrm{ng} / \mathrm{ml}$ (5.0-49.7), compared with $12.2 \mathrm{ng} / \mathrm{ml}(5.0-41.0)$ after 3 months of treatment, with $P=0.144$.

In relation to lipid profiles, there was a significant increase in mean high-density lipoprotein (HDL) cholesterol levels $(27.8 \% \pm 9.3)$ in the oral group, from $54.0 \pm 19.3 \mathrm{mg} / \mathrm{dl}$ at baseline to $68.7 \pm 24.0 \mathrm{mg} / \mathrm{dl}$ after 3 months of treatment, $P=0.003$.

There were no differences in anthropometric measurements before or after treatment with either administration route, nor were there differences in blood pressures, heart rate, glucose, insulin, C-peptide, or the HOMA index (Table 5).

Ultra-sensitive C-reactive protein results reduced significantly $(52.5 \% \pm 21.0)$ in the transdermal group, from $3.2(1.3-7.3)$ to $1.1 \mathrm{mg} / \mathrm{dl}(0.6-5.5), P=0.043$. In the oral group, there was no significant difference in ultra-sensitive C-reactive protein before and after treatment with estradiol.

Changes in IGFBP1 levels had a negative correlation with changes in insulin in the oral group $(r=-0.815$, $P<0.05)$. We also observed a strong and significant correlation between changes in triglycerides and IGFBP1 levels $(r=-0.829, P=0.042)$ in the oral group.

\section{Discussion}

In this study, we observed that IGF1 levels were significantly reduced after 3 months using $2 \mathrm{mg}$ oral estradiol, a finding that was not observed after treatment with $50 \mu \mathrm{g}$ transdermal estradiol. No significant differences were detected in IGFBP3 levels in either of the two treatment groups.

Previous studies with menopausal women have demonstrated different effects on IGF1 levels in response to the two routes of estrogen administration $(3,6,7,20$, $25,26)$. However, the treatment period (2-12 months), the dose of transdermal estradiol (20-100 $\mu \mathrm{g} /$ day), and the types and doses of oral estrogen (ethinylestradiol, $17 \beta$-estradiol, estradiol valerate, and conjugated equine 
Table 5 Comparison between the two groups in terms of changes after 3 months of treatment.

\begin{tabular}{|c|c|c|c|c|}
\hline \multirow[b]{2}{*}{ Variables } & \multicolumn{3}{|c|}{ Changes after 3 months of treatment } & \multirow[b]{2}{*}{$\boldsymbol{P}^{\mathrm{a}}$} \\
\hline & $\begin{array}{l}\text { Oral route } \\
\text { Mean } \pm \text { s.D. }\end{array}$ & $\begin{array}{l}\text { Transdermal route } \\
\text { Mean } \pm \text { S.D. }\end{array}$ & $95 \% \mathrm{Cl}$ & \\
\hline BMI $\left(\mathrm{kg} / \mathrm{m}^{2}\right)^{\mathrm{b}}$ & $0.37 \pm 0.74$ & $0.30 \pm 1.17$ & $0.07(-1.24$ to 1.38$)$ & 0.909 \\
\hline $\mathrm{WHR}^{\mathrm{b}}$ & $-0.003 \pm 0.01$ & $0.006 \pm 0.01$ & $-0.009(-0.03$ to 0.009$)$ & 0.285 \\
\hline Systolic BP $(\mathrm{mmHg})^{\mathrm{b}}$ & $2.7 \pm 10.7$ & $-2.3 \pm 13.1$ & $5.0(-11.2$ to 21.2$)$ & 0.502 \\
\hline Diastolic BP $(\mathrm{mmHg})^{\mathrm{b}}$ & $1.9 \pm 8.7$ & $3.3 \pm 6.8$ & $-1.4(-12.3$ to 9.4$)$ & 0.770 \\
\hline $\mathrm{HR}(\mathrm{bpm})^{\mathrm{b}}$ & $-7.3 \pm 12.2$ & $0.4 \pm 7.8$ & $-7.7(-22.1$ to 6.7$)$ & 0.255 \\
\hline Endometrial thickness $(\mathrm{cm})^{\mathrm{C}}$ & $0.62 \pm 0.43$ & $0.26 \pm 0.18$ & $0.36(-0.11$ to 0.83$)$ & 0.120 \\
\hline Estradiol $(\mathrm{pg} / \mathrm{ml})^{\mathrm{c}}$ & $96.9 \pm 68.1$ & $24.9 \pm 17.0$ & 72 (0.72 to 143.2$)$ & 0.048 \\
\hline IGF1 (ng/ml) ${ }^{\mathrm{C}}$ & $-132.8 \pm 122.1$ & $-14.4 \pm 67.3$ & $-118.4(-257.4$ to 20.6$)$ & 0.086 \\
\hline IGFBP3 $(\mathrm{ng} / \mathrm{ml})^{\mathrm{C}}$ & $-293.5 \pm 904.4$ & $152.6 \pm 752.9$ & -446.1 ( -1597.4 to 705.2$)$ & 0.404 \\
\hline IGFBP1 (ng/ml) ${ }^{\mathrm{C}}$ & $17.2 \pm 15.0$ & $-8.7 \pm 14.9$ & 25.9 (5.4 to 46.4$)$ & 0.019 \\
\hline Glucose $(\mathrm{mg} / \mathrm{ml})^{\mathrm{b}}$ & $-7.5 \pm 9.9$ & $-0.8 \pm 7.8$ & $-6.7(-19.1$ to 5.7$)$ & 0.252 \\
\hline Insulin $(\mu \mathrm{IU} / \mathrm{ml})^{\mathrm{c}}$ & $0.92 \pm 7.7$ & $-0.79 \pm 7.3$ & $1.71(-8.6$ to 12.0$)$ & 0.717 \\
\hline C-peptide $(\mathrm{ng} / \mathrm{ml})^{\mathrm{b}}$ & $0.46 \pm 1.19$ & $-0.34 \pm 0.82$ & $0.8(-0.62$ to 2.2$)$ & 0.233 \\
\hline HOMA $^{\mathrm{C}}$ & $-0.42 \pm 0.55$ & $-0.04 \pm 0.43$ & $-0.38(-1.06$ to 0.31$)$ & 0.249 \\
\hline Total cholesterol $(\mathrm{mg} / \mathrm{dl})^{\mathrm{b}}$ & $17.3 \pm 35.1$ & $-11.8 \pm 11.5$ & $29.1(-8.2$ to 66.4$)$ & 0.111 \\
\hline $\mathrm{HDL}(\mathrm{mg} / \mathrm{dl})^{\mathrm{b}}$ & $14.7 \pm 6.7$ & $0.0 \pm 8.9$ & 14.7 (4.0 to 25.3 ) & 0.012 \\
\hline LDL $(\mathrm{mg} / \mathrm{dl})^{\mathrm{b}}$ & $-11.0 \pm 40.0$ & $-5.0 \pm 12.7$ & $-6.0(-48.4$ to 36.4$)$ & 0.757 \\
\hline Triglycerides $(\mathrm{mg} / \mathrm{dl})^{\mathrm{b}}$ & $12.0 \pm 67.0$ & $-32.6 \pm 61.2$ & $44.6(-43.8$ to 133$)$ & 0.283 \\
\hline $\begin{array}{l}\text { Ultra-sensitive C-reactive } \\
\text { protein }\left(\mathrm{mg} / \mathrm{l}^{\mathrm{C}}\right.\end{array}$ & $-0.38 \pm 2.7$ & $-1.67 \pm 0.96$ & $1.29(-1.6$ to 4.2$)$ & 0.344 \\
\hline
\end{tabular}

$\mathrm{Cl}$, confidence interval; BMI, body mass index; WHR, waist-hip ratio; BP, blood pressure; HR, heart rate; HOMA, homeostasis model assessment. Values in bold indicate $P \leq 0.05$.

${ }^{a} V$ alue calculated with Student's $t$-test for independent samples.

${ }^{\mathrm{b}}$ Mean \pm S.D.

${ }^{\mathrm{c}}$ Median (minimum-maximum).

estrogens) differed between studies. Furthermore, most of these studies were not placebo controlled. Instead, they were longitudinal or cross-sectional studies involving small groups of patients.

Those earlier studies demonstrated 15-40\% reductions in IGF1 levels after the use of oral estrogens $(3,6,7,20,25,26)$. In our experiment, we observed a $42 \%$ reduction in IGF1 levels after $2 \mathrm{mg}$ oral estradiol was given. Helle et al. (6) employed the same type and dose of oral estrogen and observed a $16 \%$ reduction in the IGF1 levels of menopausal women. Therefore, the accentuated decrease in IGF1 observed in our experiment appears to be the result of having studied patients with $\mathrm{GH}$ deficiency, i.e. patients in whom secretion of GH could not increase in compensation.

The various effects of different routes of estrogen administration could be the result of different effects on the hepatic synthesis of IGF1. Transdermal estrogens are not subjected to the effects of the first pass through the liver and, therefore, do not cause the hepatic changes that result in reduced IGF1 $(6,7,20,26)$. Another study has also demonstrated that intranasal administration of $17 \beta$-estradiol does not modify serum IGF1 levels (27).

Oral estrogens provoke increases in HDL cholesterol without altering the remainder of the lipid profile. Although treatment with GH may result in worsened carbohydrate metabolism and cause IR (28), our data did not reveal changes in the levels of glycemia, insulin,
C-peptide or the HOMA index in response to oral estrogens.

In our sample, oral estrogens provoked a significant increase in IGFBP1 levels, which did not take place with transdermal estrogens. Another study with menopausal women showed significant increases in IGFBP1 after 3 months' use of $2 \mathrm{mg}$ oral estradiol valerate (25). A $46 \%$ increase in serum IGFBP1 levels was observed by Helle et al. (6) after oral estrogen was given to eight women who had had undetectable serum progesterone levels; the suggestion was made that this increase was due to the oral therapy.

Some authors have shown a positive correlation between low IGFBP1 levels and intermediate markers for cardiovascular disease in non-diabetic patients $(29,30)$. Another study has also demonstrated a positive correlation between low serum IGFBP1 levels and macrovascular disease and hypertension in diabetic patients, suggesting that elevated concentrations of IGFBP1 could protect against cardiovascular disease, reducing the mitogenic potential of IGFs in the vasculature (31). Low levels of IGF1 and IGFBP1, together with elevated ultrasensitive C-reactive protein levels, have also been implicated in the pathogenesis of metabolic syndrome and cardiovascular disease (32). In our experiment, we did not observe changes in ultra-sensitive C-reactive protein, in spite of the reduction in IGF 1 and the increase in IGFBP1 with the use of oral estrogens.

Because all patients included in our sample had hypopituitarism and were receiving a fixed dose of 
GH (0.5 IU/day), the variations observed in IGF1 and IGFBP1 levels were not the result of possible central effects of estrogens modifying GH secretion. In fact, these effects appear to depend primarily on the hepatic actions of oral estrogens, also responsible for the increase in HDL cholesterol (25). Moreover, since the variation in IGFBP1 was inversely correlated with variations in insulin levels in the group given oral estrogens, we might expect a reduction in insulin secretion, with a resulting increase in glycemia and/or changes in its peripheral action. However, to the extent that glycemic levels remained unaltered, with lower insulin levels, we could infer that there was an improvement in peripheral insulin action, although not expressed in the HOMA index. Nevertheless, irrespective of the mechanism involved, increases in IGFBP1 and reductions in serum IGF1 levels resulting from the oral administration of estrogen establish a situation of relative resistance to the action of $\mathrm{GH}$. These changes could be reflected clinically, with the emergence of certain abnormalities associated with GH deficiency, such as increase in trunk fat, increase in body weight, changes in the lipid profile, increase in C-reactive protein levels, and abnormalities in glucose metabolism, which were not observed in our study. These clinical abnormalities may not have occurred because of the 3-month follow-up period, which was possibly insufficient for some of these changes to be observed.

We comment about the possibility of a type 2 error in our study. Also, although the doses of estrogen administered to both groups (33) were equivalent (a daily dose of $2 \mathrm{mg}$ oral estradiol and a daily dose of $50 \mu \mathrm{g}$ transdermal estradiol), the mean serum estradiol concentration in the oral group reached higher levels, though within normal reference ranges. However, the difference between estradiol levels might have had an influence on the outcome measures because the changes in estradiol levels after 3 months of treatment were $96.9( \pm 68.1)$ and $24.9 \mathrm{pg} / \mathrm{ml}( \pm 17.0)$, $P=0.048$, in the oral and transdermal groups respectively. In addition, the changes in IGF1 levels after 3 months of treatment were not different between the two groups, $-132.8( \pm 122.1)$ in the oral group and $-14.4 \mathrm{ng} / \mathrm{ml}( \pm 67.3)$ in the transdermal group, $P=0.086$ (Table 5).

In conclusion, our preliminary data showed that the administration of oral estrogen to patients with hypopituitarism significantly reduces the $\mathrm{GH}$ action, modifying total serum IGF1 levels and possibly its free fraction. These findings suggest that estrogen replacement should be transdermally administered to these patients, with a consequent reduction in the doses of $\mathrm{GH}$ required to obtain adequate IGF1 levels. This could potentially reduce the cost of treatment and amplify the metabolic and physiological actions of $\mathrm{GH}$, with favorable repercussions for the correction of the clinical status and the improvement of the quality of life of these patients.

\section{Declaration of interest}

The authors declare that there is no conflict of interest that could be perceived as prejudicing the impartiality of the research reported.

\section{Funding}

This research did not receive any specific grant from any funding agency in the public, commercial, or not-for-profit sector.

\section{References}

1 Leung KC, Johannsson G, Leong GM \& Ho KK. Estrogen regulation of growth hormone action. Endocrine Reviews 200425 693-721. (doi:10.1210/er.2003-0035)

2 Bellantoni MF, Vittone J, Campfield AT, Bass KM, Harman SM \& Blackman MR. Effects of oral versus transdermal estrogen on the growth hormone/insulin-like growth factor I axis in younger and older postmenopausal women: a clinical research center study. Journal of Clinical Endocrinology and Metabolism $1996 \mathbf{8 1}$ 2848-2853. (doi:10.1210/jc.81.8.2848)

3 Cano A, Castelo-Branco C \& Tarín JJ. Effect of menopause and different combined estradiol-progestin regimens on basal and growth hormone-releasing hormone-stimulated serum growth hormone, insulin-like growth factor-1, insulin-like growth factor binding protein (IGFBP)-1, and IGFBP-3 levels. Fertility and Sterility 199971 261-267. (doi:10.1016/S0015-0282(98)00432-4)

4 Cardim HJ, Lopes CM, Giannella-Neto AM, da Fonseca AM \& Pinotti JA. The insulin-like growth factor-I system and hormone replacement therapy. Fertility and Sterility 200175 282-287. (doi:10.1016/S0015-0282(00)01691-5)

5 Heald A, Selby PL, White A \& Gibson M. Progestins abrogate estrogen-induced changes in the insulin-like growth factor axis. American Journal of Obstetrics and Gynecology 2000183 593-600. (doi:10.1067/mob.2000.106994)

6 Helle SI, Omsjo IH, Hughes SC, Botta L, Huls G, Holly JM \& Lonning PE. Effects of oral and transdermal oestrogen replacement therapy on plasma levels of insulin-like growth factors and IGF binding proteins 1 and 3: a cross-over study. Clinical Endocrinology 199645 727-732. (doi:10.1046/j.1365-2265.1996.8610870.x)

7 Kam GYW, Leung KC, Baxter RC \& Ho K. Estrogens exert routeand dose-dependent effects on insulin-like growth factor (IGF)binding protein-3 and the acid-labile subunit of the IGF ternary complex. Journal of Clinical Endocrinology and Metabolism $2000 \mathbf{8 5}$ 1918-1922. (doi:10.1210/jc.85.5.1918)

8 Kelly JJ, Rajkovic IA, O'Sullivan AJ, Sernia C \& Ho KK. Effects of different oral oestrogen formulations on insulin-like growth factor-I, growth hormone and growth hormone binding protein in post-menopausal women. Clinical Endocrinology 199339 561-567. (doi:10.1111/j.1365-2265.1993.tb02410.x)

9 Nugent AG, Leung KC, Sullivan D, Reutens AT \& Ho KK. Modulation by progestogens of the effects of oestrogen on hepatic endocrine function in postmenopausal women. Clinical Endocrinology 200359 690-698. (doi:10.1046/j.1365-2265.2003.01907.x)

10 O'Sullivan AJ \& Ho KK. A comparison of the effects of oral and transdermal estrogen replacement on insulin sensitivity in postmenopausal women. Journal of Clinical Endocrinology and Metabolism 199580 1783-1788. (doi:10.1210/jc.80.6.1783)

11 Goodman-Gruen D \& Barrett-Connor E. Effect of replacement estrogen on insulin-like growth factor-I in postmenopausal women: the Rancho Bernardo Study. Journal of Clinical Endocrinology and Metabolism 199681 4268-4271. (doi:10.1210/jc. 81.12.4268)

12 Gram IT, Norat T, Rinaldi S, Dossus L, Lukanova A, Tehard B, Clavel-Chapelon F, van Gils CH, van Noord PA, Peeters PH, BuenoDe-Mesquita HB, Nagel G, Linseisen J, Lahmann PH, Boeing H, Palli D, Sacerdote C, Panico S, Tumino R, Sieri S, Dorronsoro M, Quiros JR, Navarro CA, Barricarte A, Tormo MJ, Gonzalez CA, Overvad K, Paaske Johnsen S, Olsen A, Tjonneland A, Travis R, 
Allen N, Bingham S, Khaw KT, Stattin P, Trichopoulou A, Kalapothaki V, Psaltopoulou T, Casagrande C, Riboli E \& Kaaks R. Body mass index, waist circumference and waist-hip ratio and serum levels of IGF-I and IGFBP-3 in European women. International Journal of Obesity 200630 1623-1631. (doi:10. 1038/sj.ijo.0803324)

13 Holmes MD, Pollak MN \& Hankinson SE. Lifestyle correlates of plasma insulin-like growth factor I and insulin-like growth factor binding protein 3 concentrations. Cancer Epidemiology, Biomarkers and Prevention $200211862-867$.

14 Morimoto LM, Newcomb PA, White E, Bigler J \& Potter JD. Variation in plasma insulin-like growth factor-1 and insulin-like growth factor binding protein-3: personal and lifestyle factors (United States). Cancer Causes and Control 200516 917-927. (doi:10.1007/s10552-005-2702-3)

15 Vestergaard P, Hermann AP, Orskov H \& Mosekilde L. Effect of sex hormone replacement on the insulin-like growth factor system and bone mineral: a cross-sectional and longitudinal study in 595 perimenopausal women participating in the Danish Osteoporosis Prevention Study. Journal of Clinical Endocrinology and Metabolism 199984 2286-2290. (doi:10.1210/jc.84.7.2286)

16 Klaauw AA, Biermasz NR, Zelissen PMJ, Pereira A, Lentjes EGWM, Smit JWA, Thiel SW, Romijn JA \& Roelfsema F. Administration route-dependent effects of estrogens on IGF-I levels during fixed GH replacement in women with hypopituitarism. European Journal of Endocrinology 2007157 709-716. (doi:10.1530/EJE07-0412)

17 Wolthers T, Hoffman DM, Nugent AG, Duncan MW, Umpleby M \& Ho KK. Oral estrogen antagonizes the metabolic actions of growth hormone in growth hormone-deficient women. American Journal of Physiology. Endocrinology and Metabolism $2001 \mathbf{2 8 1}$ E1191-E1196.

18 Bellantoni MF, Harman SM, Cho DE \& Blackman MR. Effects of progestin-opposed transdermal estrogen administration on growth hormone and insulin-like growth factor-I in postmenopausal women of different ages. Journal of Clinical Endocrinology and Metabolism 199172 172-178. (doi:10.1210/jcem-72-1-172)

19 Ho K \& Weissberger AJ. Impact of short-term estrogen administration on growth hormone secretion and action: distinct routedependent effects on connective and bone tissue metabolism. Journal of Bone and Mineral Research 19927 821-827. (doi:10. 1002/jbmr.5650070711)

20 Weissberger AJ, Ho KK \& Lazarus L. Contrasting effects of oral and transdermal routes of estrogen replacement therapy on 24-hour growth hormone (GH) secretion, insulin-like growth factor I, and GH-binding protein in postmenopausal women. Journal of Clinical Endocrinology and Metabolism 199172 374-381. (doi:10.1210/ jcem-72-2-374)

21 Sonnet E, Lacut K, Roudaut N, Mottier D, Kerlan V \& Oger E. Effects of the route of oestrogen administration on IGF-1 and IGFBP-3 in healthy postmenopausal women: results from a randomized placebo-controlled study. Clinical Endocrinology 200766 626-631. (doi:10.1111/j.1365-2265.2007.02783.x)

22 Birzniece V, Meinnhardt U, Gibney J, Johannsson G, Baxter RC, Seibel MJ \& Ho KY. Modulatory effect of raloxifene and estrogen on the metabolic action of growth hormone in hypopituitary women. Journal of Clinical Endocrinology and Metabolism 201095 2099-2106. (doi:10.1210/jc.2009-2743)

23 Gibney J, Johannsson G, Leung KC \& Ho KY. Comparison of the metabolic effects of raloxifene and oral estrogen in postmenopausal and growth hormone-deficient women. Journal of Clinical Endocrinology and Metabolism 2005 $903897-3903$. (doi:10. 1210/jc.2005-0173)

24 Sandhu MS, Heald AH, Gibson JM, Cruickshank JK, Dunger DB \& Wareham NJ. Circulating concentrations of insulin-like growth factor-I and development of glucose intolerance. Lancet 2002359 1740-1745. (doi:10.1016/S0140-6736(02)08655-5)

25 Paassilta M, Karjalainen A, Kervinen K, Savolainen MJ, Heikkinen J, Backstrom AC \& Kesaniemi YA. Insulin-like growth factor binding protein-1 (IGFBP-1) and IGF-1 during oral and transdermal estrogen replacement therapy: relation to lipoprotein(a) levels. Atherosclerosis 2000149 157-162. (doi:10.1016/ S0021-9150(99)00318-4)

26 Karjalainen A, Paassilta M, Heikkinen J, Backstrom AC, Savolainen M \& Kesaniemi YA. Effects of peroral and transdermal oestrogen replacement therapy on glucose and insulin metabolism. Clinical Endocrinology 200154 165-173. (doi:10.1046/ j.1365-2265.2001.01208.x)

27 Garnero P, Tsouderos Y, Marton I, Pelissier C, Varin C \& Delmas PD. Effects of intranasal $17 \beta$-estradiol on bone turnover and serum insulin-like growth factor I in postmenopausal women. Journal of Clinical Endocrinology and Metabolism 1999 84 2390-2397. (doi:10. 1210/jc.84.7.2390)

28 Rizza RA, Mandarino LJ \& Gerich JE. Dose-response characteristics for effects of insulin on production and utilization of glucose in man. American Journal of Physiology. Endocrinology and Metabolism 1981240 E630-E639.

29 Heald AH, Cruickshank JK, Riste LK, Cade JE, Anderson S, Greenhalgh A, Sampayo J, Taylor W, Fraser W, White A \& Gibson JM. Close relation of fasting insulin-like growth factor binding protein-1 (IGFBP-1) with glucose tolerance and cardiovascular risk in two populations. Diabetologia 200144 333-339. (doi:10.1007/s001250051623)

30 Janssen JA, Stolk RP, Pols HA, Grobbee DE \& Lamberts SW. Serum total IGF-I, free IGF-I, and IGFBP-1 levels in an elderly population: relation to cardiovascular risk factors and disease. Arteriosclerosis, Thrombosis, and Vascular Biology 199818 277-282. (doi:10. 1161/01.ATV.18.2.277)

31 Heald AH, Siddals KW, Fraser W, Taylor W, Kaushal K, Morris J, Young RJ, White A \& Gibson JM. Low circulating levels of insulinlike growth factor binding protein-1 (IGFBP-1) are closely associated with the presence of macrovascular disease and hypertension in type 2 diabetes. Diabetes $2002512629-2636$. (doi:10.2337/diabetes.51.8.2629)

32 Kaushal K, Heald AH, Siddals KW, Sandhu MS, Dunger DB, Gibson JM \& Wareham NJ. The impact of abnormalities in IGF and inflammatory systems on the metabolic syndrome. Diabetes Care 200427 2682-2688. (doi:10.2337/diacare.27. 11.2682)

33 Scott RT Jr, Ross B, Anderson C \& Archer DF. Pharmacokinetics of percutaneous estradiol: a crossover study using a gel and a transdermal system in comparison with oral micronized estradiol. Obstetrics and Gynecology 199177 758-764.

Received 24 June 2011

Revised version received 17 November 2011

Accepted 22 November 2011 